\title{
Studies on Genetic Variability, Association and Path Coefficient Analysis in Black Gram (Vigna mungo L. Hepper)
}

\author{
N. Sathees, D. Shoba, S. Saravanan, S. Merina Perm Kumari and M. Arumugam Pillai* \\ Department of Plant Breeding and Genetics, Agricultural College and Research Institute, \\ Killikulam, Vallanad, Tuticorin-628 252, Tamil Nadu, India \\ *Corresponding author
}

\section{A B S T R A C T}

\section{Keywords}

Genetic variability,

Correlation

coefficient, Path

analysis, Black gram

Article Info

Accepted:

15 May 2019

Available Online:

10 June 2019
One hundred and sixty two $\mathrm{F}_{2}$ plants of the cross IC 436656 x KKB 14045 was phenotyped for nine quantitative characters. High PCV and GCV were observed for number of primary branches, number of clusters per plant, number of pods per plant and single plant yield. High heritability coupled with high genetic advance was registered for the traits viz., days to $50 \%$ flowering, number of clusters per plant, hundred seed weight, pod length and single plant yield suggesting the additive gene action. The trait single plant yield was significantly and positively associated with plant height, number of primary branches, number of cluster per plant, number of pods per plant, number of seeds per pod, pod length and hundred seed weight. Path analysis revealed that number of pods per plant was main component for improving the single plant yield. Hence selection of these traits would improve yield in black gram breeding programs.

\section{Introduction}

Black gram (Vigna mungo L. Hepper, 2n=22) is an important self-pollinated and short duration legume crop belonging to the family Leguminosae and sub-family Papilionaceae. India is the center of origin of black gram (Mehra et al., 2016) and black gram is cultivated as a sole crop or succeeding crop using residual moisture of preceding crop, normally cultivated after harvest of rice. India produces 1.5 to 1.9 million tons of black gram annually from about 3.5 million hectares of area, and an average productivity of $500 \mathrm{~kg}$ per hectare (Sakila et al., 2018). Black gram seeds are rich in protein (25-26 \%), carbohydrate $(60 \%)$, fat $(1.5 \%)$, minerals, amino acids and vitamins (Parveen et al., 2011). Dried black gram seeds contain high protein and lysine content which is deficient in cereals.

Generally pulses are poor yielder due to the cultivation in marginally poor soils and rainfed conditions, narrow genetic diversity, photoperiod sensitivity, indeterminate growth habit, pod shattering and susceptible to pest and diseases (Fernandez and Shanmugasundaram, 1988; Sowmini and Jayamani, 2013). The achievement of high 
yield mainly depends on the magnitude of yield contributing traits and nature of genetic variability (Johnson and Bernard, 1962). The magnitude of genetic variability is the base material for the development of new varieties (Venkatesan et al., 2005).

The correlation coefficient gives a measure of the mutual relationship between various plant characters and determines component characters on which selection is practiced for the improvement of economic important character (Hemalatha et al., 2017). The interrelationship between seed yield and plant characters are very important for making effective and viable breeding programmes for seed yield, for which direct selection is not much effective (Mathivathana et al., 2015). Path coefficient analysis is an efficient statistical technique to assess the interrelationship of different components and direct and indirect effects on seed yield (Reni et al., 2013). Hence, the present study focused on genetic variability, association and path coefficient analysis for efficient selection in black-gram breeding programs.

\section{Materials and Methods}

The experimental material consisted of $162 \mathrm{~F}_{2}$ plants derived from the cross IC $436656 \mathrm{x}$ KKB 14045. The field experiment was conducted at Department of Plant Breeding and Genetics at Agricultural college and Research Institute, Killikulam during 20182019. Biometrical traits viz., plant height $(\mathrm{cm})$, days to fifty percent flowering, number of primary branches per plant, number of clusters per plant, number of pods per plant, number of seeds per pod, pod length $(\mathrm{cm})$, hundred seed weight $(\mathrm{g})$ and single plant yield (g) were recorded. The pedigree details of the parents are given below.

All the $162 \mathrm{~F}_{2}$ plants were raised along with parents in 3 meter row with spacing of $30 \mathrm{x}$
$10 \mathrm{~cm}$ and proper agronomic practices were followed. The statistical methods suggested by Johnson et al., (1955) for various genetic variability parameters viz., genotypic coefficient of variation (GCV), phenotypic coefficient of variation (PCV), heritability and genetic advance as percentage of mean (GAM) were carried out. Genotypic correlation coefficient was worked out using the formulae given by Al-Jibouri et al., (1958) and path coefficient analysis was calculated using the formulae given by Dewey and Lu (1959). TNAUSTAT software was used for analysis of correlation and path coefficient analysis (Manivannan, 2014). The R software was used for preparing correlation chart $(\mathrm{R}$ Core Team, 2019). The direct and indirect effects were classified based on scale (Lenka and Mishra, 1973).

\section{Results and Discussion}

\section{Studies on variability parameters}

The genetic variability parameters for different plant characters were calculated and presented in Table 1. High PCV and GCV was observed for the traits viz., number of primary branches per plant $(33.26 \%$ and $21.87 \%$ respectively), number of clusters per plant (53.54 and $42.19 \%$ respectively), number of pods per plant (40.09 and 30.73\% respectively) and single plant yield (62.10and $53.30 \%$ respectively). These suggested the presence of high genetic variability present in the population and selection is effective for these traits. Sohel et al., (2016) reported similar results of high PCV and GCV for number of primary branches per plant and Sushmitharaj et al., (2018) for the traits viz., number of clusters per plant, number of pods per plant and single plant yield.

The plant characters viz., days to $50 \%$ flowering, number of seeds per pod, hundred seed weight and pod length expressed 
moderate level of PCV and GCV values. Similar results were reported by Kumar et al., (2015) for days to $50 \%$ flowering, Manjumder et al., (2011) for number of seeds per pod and Panigrahi et al., (2014) for hundred seed weight. The trait plant height showed high PCV but low GCV and similar finding was reported by Konda et al., (2008) and it indicated that the variability present in plant height was highly influenced by environmental factors.

High heritability was recorded for the traits viz., hundred seed weight $(98.36 \%)$, days to $50 \%$ flowering $(95.51 \%)$, pod length $(89.60 \%)$,single plant yield $(73.67 \%)$ and number of clusters per plant $(62.11 \%)$. High GAM was recorded for traits single plant yield $(94.24 \%)$, number of clusters per plant (68.50\%), number of pods per plant (48.53\%), hundred seed weight $(37.55 \%)$, number of primary branches per plant $(30.54 \%)$, pod length $(23.35 \%)$ and days to $50 \%$ flowering $(21.81 \%)$ on the basis of mean performance. Therefore for improving these traits simple selection would be more effective.

The pedigree details of the parents are given below

\begin{tabular}{|l|l|l|l|}
\hline SI. No & Parents & Pedigree details & Source \\
\hline 1. & IC 436656 & Land race & $\begin{array}{l}\text { National Bureau of Plant } \\
\text { Genetic Resources, New } \\
\text { Delhi }\end{array}$ \\
\hline 2. & KKB 14045 & PU-0620 x ADT-3 & $\begin{array}{l}\text { Agricultural College and } \\
\text { Research Institute, } \\
\text { Killikulam }\end{array}$ \\
\hline
\end{tabular}

Table.1 Variability parameters in $\mathrm{F}_{2}$ derivatives of the cross IC 436656 x KKB 14045

\begin{tabular}{|l|c|c|c|c|}
\hline Characters & PCV (\%) & GCV (\%) & $\left.\mathbf{( h}^{\mathbf{2}}\right)(\boldsymbol{\%})$ & GAM (\%) \\
\hline Days to 50\% flowering & 11.09 & 10.84 & $\mathbf{9 5 . 5 1}$ & $\mathbf{2 1 . 8 1}$ \\
\hline Plant height & $\mathbf{2 0 . 8 1}$ & 4.36 & 4.38 & 1.88 \\
\hline $\begin{array}{l}\text { Number of primary } \\
\text { branches/plant }\end{array}$ & $\mathbf{3 2 . 2 6}$ & $\mathbf{2 1 . 8 7}$ & 45.95 & $\mathbf{3 0 . 5 4}$ \\
\hline $\begin{array}{l}\text { Number of clusters } \\
\text { /plant }\end{array}$ & $\mathbf{5 3 . 5 4}$ & $\mathbf{4 2 . 1 9}$ & $\mathbf{6 2 . 1 1}$ & $\mathbf{6 8 . 5 0}$ \\
\hline Number of pods/plant & $\mathbf{4 0 . 0 9}$ & $\mathbf{3 0 . 7 3}$ & 58.76 & $\mathbf{4 8 . 5 3}$ \\
\hline Number of seeds/pod & 18.66 & 12.94 & 48.10 & 18.49 \\
\hline Hundred seed weight & 18.53 & 18.38 & $\mathbf{9 8 . 3 6}$ & $\mathbf{3 7 . 5 5}$ \\
\hline Pod length & 12.65 & 11.98 & $\mathbf{8 9 . 6 0}$ & $\mathbf{2 3 . 3 5}$ \\
\hline Single plant yield & $\mathbf{6 2 . 1 0}$ & $\mathbf{5 3 . 3 0}$ & $\mathbf{7 3 . 6 7}$ & $\mathbf{9 4 . 2 4}$ \\
\hline
\end{tabular}


Table. 2 Correlation coefficients among yield components in $\mathrm{F}_{2}$ derivatives of the cross IC 436656 x KKB 14045

\begin{tabular}{|c|c|c|c|c|c|c|c|c|c|}
\hline Characters & $\begin{array}{l}\text { Days to } 50 \% \\
\text { flowering }\end{array}$ & $\begin{array}{l}\text { Plant } \\
\text { height }\end{array}$ & $\begin{array}{l}\text { Number of } \\
\text { primary } \\
\text { branches/p } \\
\text { lant }\end{array}$ & $\begin{array}{l}\text { Number } \\
\text { of } \\
\text { clusters/p } \\
\text { lant }\end{array}$ & $\begin{array}{l}\text { Number } \\
\text { of pods/ } \\
\text { plant }\end{array}$ & $\begin{array}{l}\text { Number } \\
\text { of } \\
\text { seeds/pod }\end{array}$ & $\begin{array}{l}\text { Hundred } \\
\text { seed } \\
\text { weight }\end{array}$ & $\begin{array}{l}\text { Pod } \\
\text { length }\end{array}$ & $\begin{array}{l}\text { Single } \\
\text { Plant } \\
\text { yield }\end{array}$ \\
\hline $\begin{array}{l}\text { Days to } 50 \% \\
\text { flowering }\end{array}$ & 1.000 & & & & & & & & \\
\hline Plant height & 0.061 & 1.000 & & & & & & & \\
\hline $\begin{array}{l}\text { Number of } \\
\text { primary } \\
\text { branches/plant }\end{array}$ & -0.131 & $0.439 * *$ & 1.000 & & & & & & \\
\hline $\begin{array}{l}\text { Number of } \\
\text { clusters/plant }\end{array}$ & -0.127 & $0.612 * *$ & $0.671 * *$ & 1.000 & & & & & \\
\hline $\begin{array}{l}\text { Number of } \\
\text { pods/plant }\end{array}$ & -0.135 & $0.658 * *$ & $0.523 * *$ & $0.868 * *$ & 1.000 & & & & \\
\hline $\begin{array}{l}\text { Number of } \\
\text { seeds/pod }\end{array}$ & $-0.283 * *$ & $0.274 * *$ & $0.222 *$ & $0.338 * *$ & $0.296 * *$ & 1.000 & & & \\
\hline $\begin{array}{l}\text { Hundred seed } \\
\text { weight }\end{array}$ & 0.001 & $0.333 * *$ & $0.215^{*}$ & $0.181 *$ & 0.148 & $0.282 * *$ & 1.000 & & \\
\hline Pod length & -0.108 & $0.298 * *$ & $0.232 * *$ & $0.243 * *$ & $0.203^{*}$ & $0.671 * *$ & $0.465 * *$ & 1.000 & \\
\hline Single Plant yield & $-0.169 *$ & $0.649 * *$ & $0.441 * *$ & $0.779 * *$ & $0.852 * *$ & $0.524 * *$ & $0.387 * *$ & $0.410 * *$ & 1.000 \\
\hline
\end{tabular}

** Significant at $1 \%$ level; * Significant at $5 \%$ level

Table.3 Direct and indirect effects of different traits on yield in $\mathrm{F}_{2}$ derivatives of the cross IC 436656 x KKB 14045

\begin{tabular}{|l|l|l|l|l|l|l|l|l|l|}
\hline Characters & $\begin{array}{l}\text { Days to } \\
\text { 50 \% } \\
\text { flowering }\end{array}$ & $\begin{array}{l}\text { Plant } \\
\text { height } \\
\text { (cm) }\end{array}$ & $\begin{array}{l}\text { Number of } \\
\text { primary } \\
\text { branches/ } \\
\text { plant }\end{array}$ & $\begin{array}{l}\text { Number } \\
\text { of } \\
\text { clusters/ } \\
\text { plant }\end{array}$ & $\begin{array}{l}\text { Number of } \\
\text { pods/plant }\end{array}$ & $\begin{array}{l}\text { Number of } \\
\text { seeds/pod }\end{array}$ & $\begin{array}{l}\text { Hundred } \\
\text { seed } \\
\text { weight }(\mathbf{g})\end{array}$ & $\begin{array}{l}\text { Pod } \\
\text { length } \\
\text { (cm) }\end{array}$ & $\begin{array}{l}\text { Single } \\
\text { plant } \\
\text { yield } \\
\text { (g) }\end{array}$ \\
\hline $\begin{array}{l}\text { Days to 50 \% } \\
\text { flowering }\end{array}$ & $\mathbf{- 0 . 0 1 4 7}$ & 0.0031 & 0.0149 & -0.0164 & -0.0904 & -0.0658 & 0.0003 & -0.0001 & -0.1690 \\
\hline $\begin{array}{l}\text { Plant height } \\
\text { (cm) }\end{array}$ & -0.0009 & $\mathbf{0 . 0 5 0 7}$ & -0.0498 & 0.0784 & 0.4379 & 0.0637 & 0.0689 & 0.0002 & 0.6491 \\
\hline $\begin{array}{l}\text { Number of } \\
\text { primary } \\
\text { branches/plt }\end{array}$ & 0.0019 & 0.0223 & $\mathbf{- 0 . 1 1 3 3}$ & 0.0859 & 0.3484 & 0.0517 & 0.0445 & 0.0002 & 0.4416 \\
\hline $\begin{array}{l}\text { Number of } \\
\text { cluster /plant }\end{array}$ & 0.0019 & 0.0311 & -0.0761 & $\mathbf{0 . 1 2 7 9}$ & 0.5780 & 0.0786 & 0.0375 & 0.0002 & 0.7791 \\
\hline $\begin{array}{l}\text { Number of } \\
\text { pods / plant }\end{array}$ & 0.0020 & 0.0334 & -0.0593 & 0.1111 & $\mathbf{0 . 6 6 5 4}$ & 0.0689 & 0.0308 & 0.0001 & 0.8523 \\
\hline $\begin{array}{l}\text { Number of } \\
\text { seeds /pod }\end{array}$ & 0.0042 & 0.0139 & -0.0252 & 0.0433 & 0.1971 & $\mathbf{0 . 2 3 2 5}$ & 0.0583 & 0.0005 & 0.5245 \\
\hline $\begin{array}{l}\text { Hundred seed } \\
\text { weight (g) }\end{array}$ & -0.0000 & 0.0169 & -0.0244 & 0.0232 & 0.0990 & 0.0656 & $\mathbf{0 . 2 0 6 8}$ & 0.0003 & 0.3874 \\
\hline $\begin{array}{l}\text { Pod length } \\
\text { (cm) }\end{array}$ & 0.0016 & 0.0151 & -0.0263 & 0.0311 & 0.1353 & 0.1561 & 0.0963 & $\mathbf{0 . 0 0 0 7}$ & 0.4100 \\
\hline
\end{tabular}

Residual effect: 0.38 
Fig.1 Chart of correlation matrix between different traits in $\mathrm{F}_{2}$ derivatives of the cross IC 436656 X KKB 14045

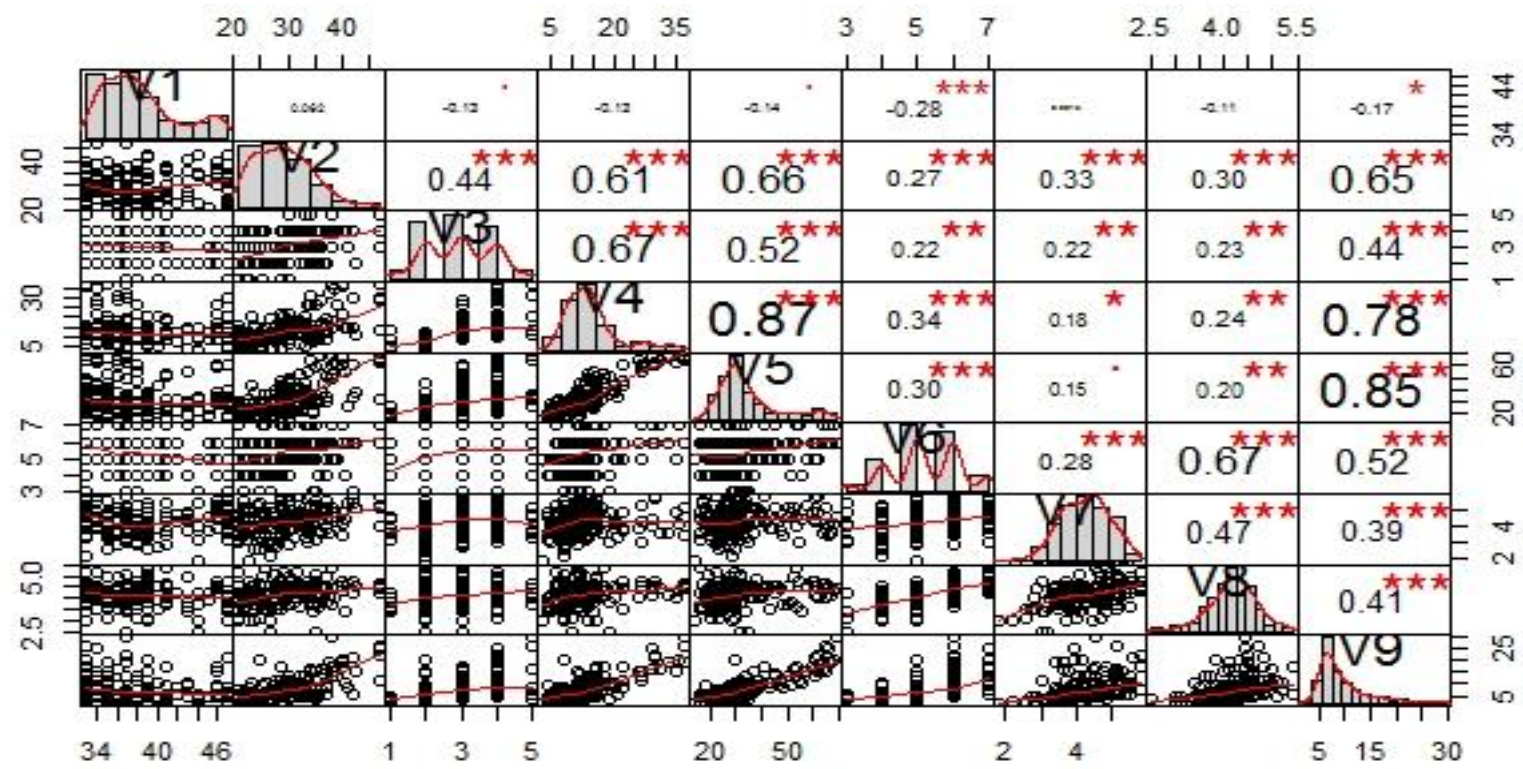

(Note: V1-Days to 50\% flowering, V2-Plant height, V3-Number of primary branches, V4-Number of cluster per plant, V5-Number of pods per plant, V6-Number of seeds per pod, V7-Hundred seed weight, V8-Pod length, V9Single plant yield).

High heritability coupled with high GAM was registered for days to $50 \%$ flowering, number of clusters per plant, hundred seed weight, pod length and single plant yield suggesting additive gene action for the genetic control of these traits. Konda et al., (2008) reported similar finding for days to $50 \%$ flowering; Sushmitharaj et al., (2018) for number of clusters per plant and single plant yield; Usharani and Kumar (2015) for hundred seed weight and Veeramani et al., (2005) for pod length.

\section{Studies on association between traits}

The correlation between the traits is presented in Table 2 and Figure 1. The trait single plant yield had significant and positive association with plant height $(0.649)$, number of primary branches per plant $(0.441)$, number of clusters per plant (0.779), number of pods per plant (0.852), number of seeds per pod (0.524), pod length (0.387) and hundred seed weight (0.410) and also significant and negative association with days to $50 \%$ flowering. These traits could be targeted for improvement of single plant yield. Similar significant and positive association was reported by Sushmitharaj et al., (2018) for plant height, number of clusters per plant and number of pods per plant; Keerthiga et al., (2018) for number of primary branches per plant, number of seeds per pod and hundred seed weight and Rami Reddy et al., (2011) for pod length.

From inter correlation studies, days to $50 \%$ flowering was significant and negative association with number of seeds per pod and single plant yield. Plant height had significant and positive association with number of primary branches per plant, number of clusters per plant, number of pods per plant, number of seeds per pod, hundred seed weight, pod length and single plant yield. Number of primary branches showed positive and significant association with number of clusters per plant, number of pods per plant, 
number of seeds per pod, hundred seed weight, pod length and single plant yield. Number of clusters per plant showed positive and significant association with number of pods per plant, number of seeds per pod, hundred seed weight, pod length and single plant yield. Number of pods per plant exhibited positive and significant association with number of seeds per pod, pod length and single plant yield. Number of seeds per pod showed positive and significant association with hundred seed weight, pod length and single plant yield. Hundred seed weight expressed positive and significant association with pod length and single plant yield. Pod length exhibited positive and significant association with and single plant yield. Hence selection of these traits would improve the plant yield in black gram.

\section{Studies on path coefficient analysis}

The results on path coefficient analysis are presented in Table 3. The trait number of pods per plant showed high, positive and direct effect on single plant yield. Sathya et al., (2018) reported a similar result. Number of seeds per pod showed moderate, positive and direct effect on single plant yield. Plant height and pod length showed very low, positive and direct effect on single plant yield. Number of primary branches showed low, negative and direct effect on single plant yield. Days to 50 $\%$ flowering showed very low, negative and direct effect on single plant yield.

Similar results were carried out by Parveen $e t$ al., (2011). Number of clusters per plant, plant height and number of primary branches showed high, positive and indirect effect on single plant yield through number of pods per plant. Number of seeds per pod and pod length showed low, positive and indirect effect on single plant yield through number of pods per plant.

\section{References}

Al-Jibouri, H., Miller, P. A., and Robinson, H. F. 1958. Genotypic and environmental variances and covariances in an upland cotton cross of interspecific origin. Agronomy Journal. 50(10): 633-636.

Dewey, D. R., and Lu, K. 1959. A Correlation and Path-Coefficient Analysis of Components of Crested Wheatgrass Seed Production. Agronomy Journal. 51(9):515-518.

Fernandez, G. C. J., and Shanmugasundaram, S. 1988. The AVRDC mungbean improvement program: the past, present and future. In Mungbean. Proceedings of the Second International Symposium held at Bangkok, Thailand, 16-20 November 1987. pp. 58-70. AVRDC.

Hemalatha, K., Lal, S. S., and Lal, G. M. 2017. Study on Genetic Variability and Correlation in Black gram (Vigna mungo L. Hepper). Journal of Pharmacognosy and Phytochemistry. 6(4): 674-676.

Johnson, H.W., and Bernard, R.L. 1962. Soybean genetics and breeding. In Advances in Agronomy. 14:149-221.

Johnson, H.W., Robinson, H.F., and Comstock, R. 1955. Estimates of genetic and environmental variability in soybeans. Agronomy Journal. 47(7): 314-318.

Keerthiga, S., Sen, S., Pandya, H. R., and Modha, K. G. 2018. Correlation and path analysis in $\mathrm{F}_{4}$ progenies of green gram [Vigna radiata (L.) R. Wilczek] for seed yield and its attributes. International Journal of Current Microbiology and Applied Sciences. 7(1): 710-719.

Konda, C. R., Salimath, P. M., and Mishra, M. N. 2008. Correlation and path coefficient analysis in black gram [Vigna mungo (L.) Hepper]. Legume 
Research-An International Journal. 31(3):202-205.

Kumar, G.V., Vanaja, M., Lakshmi, N.J., and Maheswari, M. 2015. Studies on variability, heritability and genetic advance for quantitative traits in blackgram (Vigna mungo (L.) Hepper). Agricultural Research Journal, 52(4): 28-31.

Lenka, D., and Misra, B. 1973. Pathcoefficient analysis of yield in rice varieties. Indian Journal of Agricultural Sciences. 43(4):376-379.

Majumder, N.D., Mandal, A.B., Ram, T., and Kar, C.S. 2011. Assessment of genetic diversity and other genetic parameters in blackgram. Crop Improvement. 38(1):35-37.

Manivannan, N., 2014. TNAUSTATStatistical package. Retrived from https://sites.google.com/site/tnaustat.

Mathivathana, M.K., Shunmugavalli, N., Muthuswamy, A., and Harris, C. V. 2015. Correlation and path analysis in black gram. Agricultural Science Digest. 35(2):158-160.

Mehra, R., Tikle, A.N., Saxena, A., Munjal, A., and Singh, M. 2016. Correlation, path coefficient and genetic diversity in black gram (Vigna mungo (L) Hepper). International Research Journal of Plant Science. 7(1):001-011.

Panigrahi, K.K., Baisakh, B., Kar, M., and Mohanty, A., 2014. Genetic divergence in mutants and land races of black gram (Vigna mungo [L.] Hepper) from Odisha. Electronic Journal of Plant Breeding. 5(3):567-572.

Parveen, S.I., Sekhar, M.R., Reddy, D.M., and Sudhakar, P.2011. Correlation and path coefficient analysis for yield and yield components in black gram (Vigna mungo (L.) Hepper). International Journal of Applied Biology and Pharmaceutical Technology. 2(3): 619625.
R Core Team, 2019. R: A language and environment for statistical computing. $\mathrm{R}$ Foundation for Statistical Computing, Vienna, Austria. https://www.Rproject.org/.

Rami Reddy, D.K., Venkateswarlu, O., Jyothi, G.L., and Obaiah, M.C. 2011. Genetic parameters and interrelationship analysis in black gram [Vigna mungo (L.) Hepper]. Legume Research: An International Journal. 34(2).

Reni, Y.P., Rao, Y.K., Satish, Y., and Babu, J. S. 2013. Estimates of genetic parameters and path analysis in black gram (Vigna mungo (L.) Hepper). International Journal of Plant Animal and Environmental Sciences. 3(4):231234.

Sakila, M., and Pandiyan, M., 2018. Realization of facts and profiteering of black gram through different breeding methods. International Journal of Communication System. 6(4): 33593369.

Sathya, P., Manivannan, N., Mahalingam, A., Satya, V. K., and Parameswari, C., 2018. Association analysis for seed yield and component traits in segregating populations of black gram (Vigna mungo (L.) Hepper). Electronic Journal of Plant Breeding. 9(2):741746.

Sohel, M.H., Miah, M.R., Mohiuddin, S.J., Islam, A.K.M.S., Rahman, M.M., and Haque, M.A., 2016. Correlation and path coefficient analysis of black gram (Vigna mungo L.). Journal of Bioscience and Agricultural Research. 7(02): 621-629.

Sowmini, K., and Jayamani, P. 2013. Genetic variability studies for yield and its component traits in RIL population of black gram (Vigna mungo (L.) Hepper). Electronic Journal of Plant Breeding. 4(1):1050-1055. 
Sushmitharaj, D.V., Shoba, D., and Pillai, M.A. 2018. Genetic variability and correlation studies in black gram (Vigna mungo [L.] hepper) with reference to YMV resistance. International Journal of Current Microbiology and Applied Sciences. Special Issue 6: 2849-2856.

Usharani, K.S., and Kumar, C.A. 2015. Induced polygenic variability using combination treatment of gamma rays and ethyl methane sulphonate in black gram (Vigna mungo (L.) Hepper). African Journal of Biotechnology. 14(20):1702-1709.
Veeramani, V.N., Thangavel, P., and Ganesan, J. 2005. Genetic variability, heritability and genetic advance analysis in segregating generation of black gram. Legume Research. 28: 49-51.

Venkatesan, N.M., Thangavel, P., and Ganesan, J. 2005. Genetic variability, heritability and genetic advance analysis in segregating generation of black gram (Vigna mungo (L.) hepper\}. Legume Research-An International Journal. 28(1): 49-51.

\section{How to cite this article:}

Sathees, N., D. Shoba, S. Saravanan, S. Merina Perm Kumari and Arumugam Pillai, M. 2019. Studies on Genetic Variability, Association and Path Coefficient Analysis in Black Gram (Vigna mungo L. Hepper). Int.J.Curr.Microbiol.App.Sci. 8(06): 1892-1899.

doi: https://doi.org/10.20546/ijcmas.2019.806.227 